\section{ASTERINA DRYPETIGENA A NEW SPECIES OF FUNGUS FROM SHIVAMOGGA, KARNATAKA, INDIA}

\section{V.B. Hosagoudar ${ }^{1}$ \& Sony Thomas ${ }^{2}$}

1,2 Jawaharlal Nehru Tropical Botanic Garden and Research institute, Palode, Thiruvananthapuram, Kerala 695562, India

${ }^{1}$ vbhosagoudar@rediffmail.com (corresponding author), ${ }^{2}$ sonytv@hotmail.com

The genus Drypetes belonging to the family Euphorbiaceae, globally comprises about 200 species of which 15 are in India (Santapau \& Henry 1984). Drypetes roxburghii, a native of India, Sri Lanka and South East Asia, commonly occurs throughout the southern Western Ghats, growing in the remnants of the evergreen forests of Shivamogga District in Karnataka State found infected with black mildew fungus. Microscopic examination of the infected fungus revealed that it is hitherto undescribed species of the genus Asterina, hence the description.

\section{Asterina drypetigena sp. nov.}

(Fig. 1; MB No. 803979)

Colonies epiphyllous, dense, up to $2 \mathrm{~mm}$ in diameter. Hyphae substraight to undulate, branching alternate to unilateral at acute to wide angles, loosely reticulate, cells $16-24 \times 3-5 \mu \mathrm{m}$. Appressoria unicellular, alternate to unilateral, ovate, clavate, often attenuated towards the apex but broadly rounded, straight to often slightly curved, entire, 9-13x4-5 $\mu \mathrm{m}$. Thyriothecia scattered to connate, orbicular, up to $200 \mu \mathrm{m}$ in diameter, margin crenate, stellately dehisced at the centre; asci globose, ovate, octosporous, up to $25 \mu \mathrm{m}$ in diam.; ascospores brown, conglobate, cylindrical, ovate, uniseptate, slightly constricted at the septum, 1520x7-10 $\mu \mathrm{m}$

Materials examined:TBGT 6007 (holotype), 07.ii.2012, on leaves of Drypetes roxburghii (Wallich)

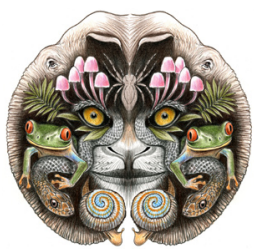

ISSN Print 0974-7893

\section{OPEN ACCESS}

Online 0974-7907 near Maryland plantations, Mavinakatte, Hosanagar, Shivamogga, Karnataka, coll. Sony Thomas.

Asterina drypetis Ryan on Drypetes sp. from Porto Rico and Asterina drypeticola Petrak \& Cif. on Drypetes glauca from Dominican Islands are reported (Ryan 1924;

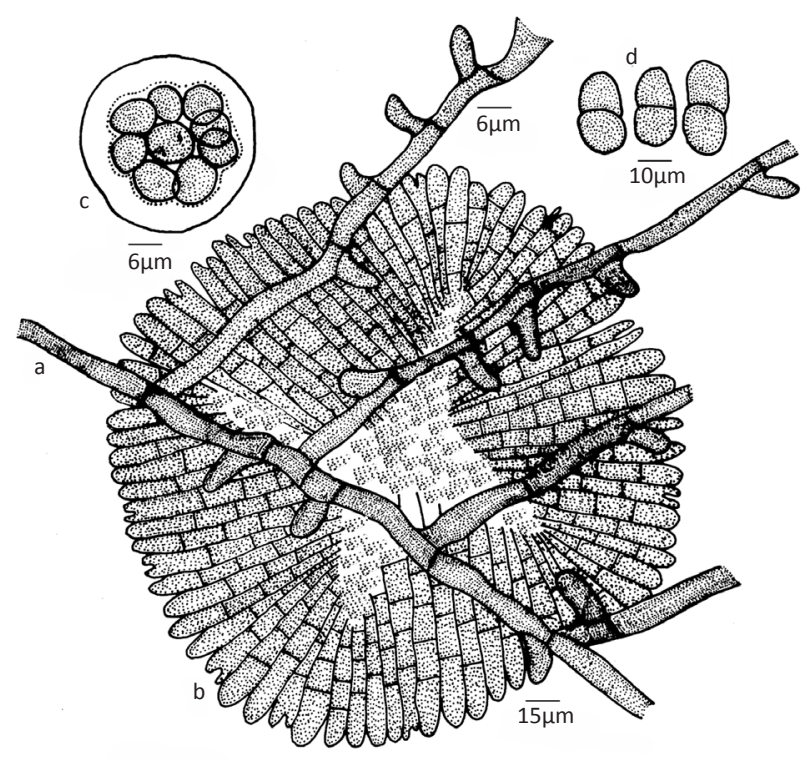

Figure 1. Asterina drypetigena sp. nov.

a - Appressoriate mycelium; b - Thyriothecium; c - Ascus; d - Ascospores

DOI: http://dx.doi.org/10.11609/JoTT.o3233.4420-1

Editor: R.K. Verma, Tropical Forest Research Institute, Jabalpur, India.

Date of publication: 26 May 2013 (online \& print)

Manuscript details: Ms \# 03233 | Received 06 June 2012 | Final received 09 April 2013 | Finally accepted 12 April 2013

Citation: Hosagoudar, V.B. \& S. Thomas (2013). Asterina drypetigena a new species of fungus from Shivamogga, Karnataka, India. Journal of Threatened Taxa 5(9): 4420-4421; http://dx.doi.org/10.11609/JoTT.03233.4420-1

Copyright: (c) Hosagoudar \& Thomas 2013. Creative Commons Attribution 3.0 Unported License. JoTT allows unrestricted use of this article in any medium, reproduction and distribution by providing adequate credit to the authors and the source of publication.

Funding: Jawaharlal Nehru Tropical Botanic Garden and Research institute, Palode, Thiruvananthapuram, Kerala, India

Competing Interest: None.

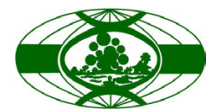

Acknowledgements: Thanks are due to Dr. P.G. Latha, Director, JNTBGRI, Palode for the facilities and (ST) is grateful to Dr. P.N. Krishnan and Dr. C.K. Biju, Scientists, JNTBGRI, Palode for their encouragement. 
Petrak \& Cifferi 1932). However, Asterina drypetigena sp. nov. differs from the former species in having entire appressoria and smaller ascospores (15-20x8-10 $\mu \mathrm{m}$ vs 28-31x10-12 $\mu \mathrm{m})$ and from the latter taxon in having distinctly smaller ascospores (15-20x8-10 $\mu \mathrm{m}$ vs 3038x14-18 $\mu \mathrm{m}$ ).

Etymology: Named after the host genus.

\section{REFERENCES}

Ryan, R.W. (1924). The Microthyriaceae of Porto Rico. Mycologia 16: 177-196.

Petrak, F. \& R.Ciferri (1932). Fungi Dominicani. II. Annales Mycologici 30: 149-353.

Santapau, H. \& A.N.Henry (1984). A Dictionary of the Flowering Plants in India. CSIR, New Delhi, 198pp. 